\title{
Greywater Characteristics, Treatment Systems, Reuse Strategies and User Perception-a Review
}

\author{
Michael Oteng-Peprah (D) - Mike Agbesi Acheampong • \\ Nanne K. deVries
}

Received: 20 February 2018 / Accepted: 4 July 2018 /Published online: 16 July 2018

(C) The Author(s) 2018

\begin{abstract}
This paper presents a literature review of the quality of greywater generated in different, especially developing, countries, constituents found in greywater, some treatment systems, natural materials for treatment, some reuse strategies and public perception regarding greywater reuse. The review shows that generation rates are mostly influenced by lifestyle, types of fixtures used and climatic conditions. Contaminants found in greywater are largely associated with the type of detergent used and influenced by other household practices. Many of the treatment systems reviewed were unable to provide total treatment as each system has its unique strength in removing a group of targeted pollutants. The review revealed that some naturally occurring materials such as Moringa oleifera, sawdust, can be used to remove targeted pollutants in greywater. The study
\end{abstract}

M. Oteng-Peprah $(\bowtie) \cdot$ N. K. deVries

Department of Health Promotion, Faculty of Health Medicine and Life Sciences, University of Maastricht, Peter Debyplein 1, 6229

HA Maastricht, The Netherlands

e-mail: m.oteng-peprah@maastrichtuniversity.nl

e-mail: Moteng-peprah@ucc.edu.gh

N. K. deVries

e-mail: n.devries@maastrichtuniversity.nl

M. Oteng-Peprah

Department of Chemistry, University of Cape Coast, Cape Coast, Ghana

M. A. Acheampong

Department of Chemical Engineering, School of Engineering,

Kumasi Technical University, Kumasi, Ghana

e-mail: Dadarf@yahoo.com further showed that user perceptions towards greywater treatment and reuse were only favourable towards nonpotable purposes, mostly due to perceived contamination or lack of trust in the level of treatment offered by the treatment system.

Keywords Greywater Reuse · Natural media ·

Treatment systems $\cdot$ User perception

\section{Introduction}

The total volume of freshwater on Earth far outweighs the human demands. Out of the overall water resources on Earth, about $97 \%$ can be found in the oceans while the remaining 3\% remains available for direct exploitation; however, out of this $3 \%$, the quantity of water that is available for use by humans is estimated at onehundredth (Eakin and Sharman 2010; Gleick 1993). Uneven distribution of water in both time and space sways the use of water to other geographical areas depriving others of this resource. Biological survival remains one of the key factors of water use with its associated use also for household needs and for food production and other developmental needs. Many parts of the world are hit by acute water shortage, overexploitation of water resources leading to gradual destruction of these water resources and high levels of freshwater pollution resulting from anthropogenic factors. Currently, it has been estimated that about 800 million people live under a threshold of water stress and this number is expected to reach 3 billion in 2025 
(Qureshi and Hanjra 2010; UNDP 2017). Due to urbanization, industrialization and population growth, the demand for water is evident; however, will the available water resources meet the ever-growing needs in a sustainable manner? Where will the extra water that is required to sustain human activities come from? This question calls for interventions and strategies that will help address these concerns. This is where a cursory look at greywater reuse is worthwhile.

Greywater is defined as wastewater without any contributions from toilet water (Casanova et al. 2001; Ledin et al. 2001; Ottoson and Stenstrom 2003). It is considered high volume, low strength wastewater with high potential for reuse and application. The composition of greywater is varied and depends on the lifestyle, fixtures and climatic conditions (Abedin and Rakib 2013; do Couto et al. 2013; Katukiza et al. 2014). Reuse of greywater has been an old practice, and it is still being done in areas that are water stressed. This practice if given the needed attention can help reduce the overreliance on freshwater resources and reduce the pollution caused by discharge of untreated greywater into freshwater resources. It can also be a supplementary source to existing water sources in areas where there is acute water crisis or in arid climatic regions. Recycled greywater can be used for different water-demanding activities including potable and non-potable uses such as toilet flushing and agriculture. The major concerns with greywater reuse have been issues with public health perceptions and inappropriate technology for the reuse option (Vigneswaran and Sundaravadivel 2004). Many researchers have studied characteristics of greywater with respect to fixtures, life style patterns and type of settlement (Alsulaili and Hamoda 2015; do Couto et al. 2013; Katukiza et al. 2014). However, the aim of this study is to assess the performance of greywater treatment system, to further review greywater reuse perceptions, to identify gaps of greywater systems with emphasis on developing countries and to identify scope for further research. This review used resources from peer reviewed journals, documents from the internet and text books. The methodological framework that guided this review is presented in Fig. 1.

\section{Greywater Quantity}

Greywater reuse has been considered as a reliable method of ensuring water security as compared to other methods of water capture such as rainwater harvesting which is dependent on hydrological conditions. The amount of greywater produced in a household can vary greatly ranging from as low as $15 \mathrm{~L}$ per person per day for poor areas to several hundred per person per day. Factors that account for such huge disparities are mostly attributed to geographical location, lifestyle, climatic conditions, type of infrastructure, culture and habits, among others. Greywater accounts for up to $75 \%$ of the wastewater volume produced by households, and this can increase to about $90 \%$ if dry toilets are used (Hernandez Leal et al. 2010). It has also been estimated that greywater produced accounts for about $69 \%$ of domestic water consumption (Jamrah et al. 2011). Table 1 presents different greywater generation rates in some reported studies in different countries.

\section{Greywater Composition}

The composition of greywater varies, and it is largely a reflection of the lifestyle and the type and choice of chemicals used for laundry, cleaning and bathing. The quality of the water supply and the type of distribution network also affect the characteristics of greywater. There will be significant variations in the composition of greywater in both place and time which may be due to variations in water usage in relation to the discharged quantity. The composition may also be affected by chemical and biological degradations of some compounds within the transportation and storage network. Generally, greywater contains high concentrations of easily biodegradable organic materials and some basic constituents which are largely generated from households. These include nutrients such as nitrates and all its derivatives, phosphorus and its derivatives, but others include xenobiotic organic compounds (XOCs) (FattaKassinos et al. 2011) and biological microbes such as faecal coliforms, salmonella and general hydrochemical constituents. Recent studies have however found pharmaceuticals, health and beauty products, aerosols, pigments (Eriksson et al. 2003) and toxic heavy metals such as $\mathrm{Pb}, \mathrm{Ni} \mathrm{Cd}, \mathrm{Cu}, \mathrm{Hg}$ and $\mathrm{Cr}$ (Aonghusa and Gray 2002; Eriksson et al. 2010) in appreciable concentrations in greywater. The presence of these contaminants in greywater is an indication of the gradual increase in the level of complexity in the composition of greywater. 

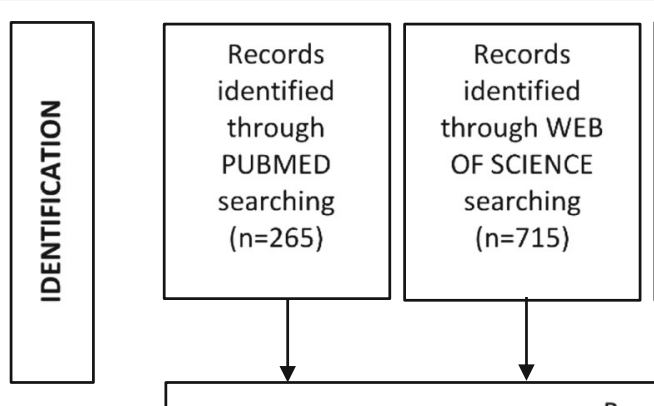

Technical
briefs, Text
books and
dissertations
$(n=9)$
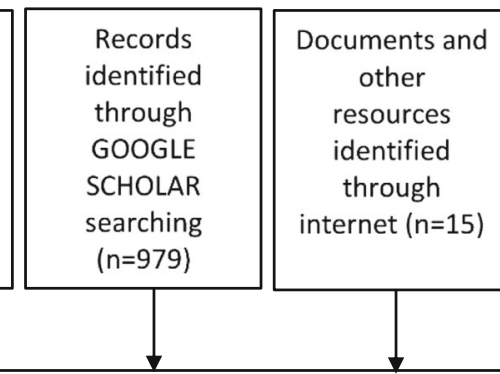

Records identified $(n=1,983)$

Records after duplicates removed $(n=1,983-1,219=764)$
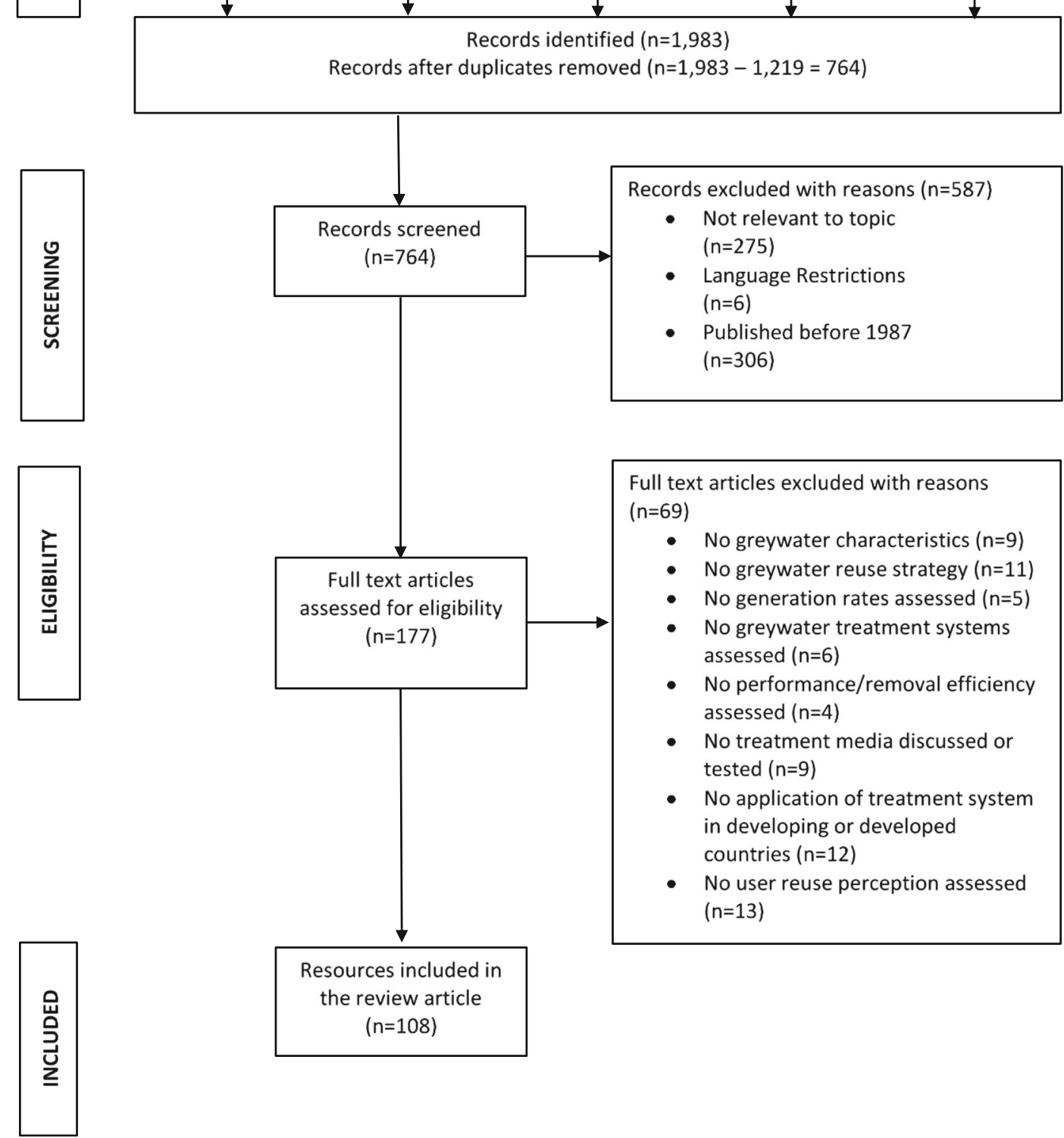

Full text articles excluded with reasons $(n=69)$

- No greywater characteristics ( $n=9)$

- No greywater reuse strategy $(n=11)$

- No generation rates assessed $(n=5)$

- No greywater treatment systems assessed $(n=6)$

- No performance/removal efficiency assessed $(n=4)$

- No treatment media discussed or tested $(n=9)$

- No application of treatment system in developing or developed countries ( $n=12$ )

- No user reuse perception assessed $(n=13)$

Fig. 1 Methodological framework

\section{Physical Constituents}

These are constituents that are associated with the physical appearance of greywater and include temperature, turbidity, electrical conductivity and suspended solids, among others. Greywater normally has temperature range of between 18 and $35{ }^{\circ} \mathrm{C}$, and the rather high temperature may be originating from warm water used 
Table 1 Greywater generation rates in different studies

\begin{tabular}{lll}
\hline Location & Generation (/Lc/day) & Reference \\
\hline Africa and Middle East & $14-161$ & $\begin{array}{c}\text { Al-Hamaiedeh and Bino (2010); } \\
\text { Halalsheh et al. (2008); } \\
\text { Morel and Diener (2006) }\end{array}$ \\
Asia & & Morel and Diener (2006) \\
Gauteng, South Africa & $20-225$ & Adendorff and Stimie (2005) \\
Jordan & 50 & Faraqui and Al-Jayyousi (2002) \\
Mali & 30 & Alderlieste and Langeveld (2005) \\
Muscat, Oman & 151 & Jamrah et al. (2008) \\
Nepal & 72 & Shresta (1999) \\
Stockholm & 65 & Ottoson and Stenstrom (2003) \\
Tucson Arizona, USA & 123 & Casanova et al. (2001) \\
Vietnam & $80-110$ & Busser et al. (2006)
\end{tabular}

for personal hygiene and cooking activities. These high temperatures may favour microbiological growth which is undesirable and may also cause precipitation of certain carbonates such as $\mathrm{CaCO}_{3}$ and other inorganic salts which become less soluble at high temperatures. The concentration of total suspended solids in greywater can range within 190-537 $\mathrm{mg} / \mathrm{L}$ as has been reported (Edwin et al. 2014; Oteng-Peprah et al. 2018). Greywater with much of the water originating from the kitchen and laundry accounts for the relatively high values of total suspended solids (TSS), and this may be due to washing of clothes, shoes, vegetables, fruits, tubers and many others which may contain sand, clay and other materials that could increase TSS. The ranges recorded for electrical conductivity in greywater is between 14 and $3000 \mu \mathrm{S} / \mathrm{cm}$ (Ciabatti et al. 2009; Prathapar et al. 2005). Groundwater sources and water scarce areas are mostly associated with high electrical conductivity due to dissolved materials. Poor or old plumbing materials also contribute to the increase in electrical conductivity due to leaching into greywater sources. The range of turbidity recorded for greywater is between 19 and 444 NTU, and it is mostly influenced by the water use activities. Greywater that has most of its sources originating from the kitchen and laundry is expected to become more turbid due to the presence of suspended matter.

\section{Chemical Contaminants}

To identify the different chemical constituents in greywater, it is important to understand the sources of contaminants. Significant chemical constituents in greywater are from chemicals used for cleaning, cooking and bathing purposes. The $\mathrm{pH}$ in greywater to a large extent depends on the $\mathrm{pH}$ and alkalinity in the water supply and normally is within the range of 5-9. Greywater with most of its sources originating from the laundry will generally exhibit high $\mathrm{pH}$ due to the presence of alkaline materials used in detergents. The major chemical constituents found in greywater which is generated as a result of cleaning or washing activities are surfactant. These surfactants serve as the main active agent in most cleaning products. They can be either cationic or anionic in nature with a majority of cleaning and laundry products being anionic (Jakobi and Lohr 1987). Cationic surfactants are generally salt based, and they constitute a source of ammonium in the greywater. Other constituents found in greywater also include nitrates and phosphate which are reportedly from ammonium and cationic surfactants and laundry disinfectants respectively (Eriksson et al. 2002). Other constituents such as sodium which is also from cooking and preservation activities in the kitchen can also be found in appreciable levels. Sodium-based soaps also contribute significant quantity of sodium into greywater. Other additives such as builders control water hardness in detergents and also serve as the main source of phosphate contaminant in greywater (Lange 1994). Nutrients such as $\mathrm{N}$ and $\mathrm{P}$ are associated with kitchen and laundry activities. Greywater sources with high nutrients concentrations are mostly made up of a high fraction of kitchen and laundry sources (Boyjoo et al. 2013). Kitchen waste are the primary source of nitrogen in greywater and range between 4 and $74 \mathrm{mg} / \mathrm{L}$ while washing 
detergents are the primary source of phosphates found in grey water which also range between 4 and $14 \mathrm{mg} / \mathrm{L}$ (Boyjoo et al. 2013).

The conventional wastewater parameters such as biochemical oxygen demand $\left(\mathrm{BOD}_{5}\right)$ and chemical oxygen demand (COD) always show a dominance of COD over $\mathrm{BOD}_{5}$. The biodegradability of greywater is determined by the $\mathrm{BOD}_{5} / \mathrm{COD}$ ratios. The ratio determines the ease with which bacteria can decompose the organic matter in the greywater. Mostly, all types of greywater show good biodegradability in terms of the $\mathrm{BOD}_{5} / \mathrm{COD}$ ratios ( $\mathrm{Li}$ et al. 2009). The average $\mathrm{BOD}_{5} / \mathrm{COD}$ ratios in greywater have ranged between 0.31 and 0.71 which is an indication that almost half of the organic matter in greywater is biodegradable (Halalsheh et al. 2008). However, other studies have recorded ratios as high as 4:1 (Boyjoo et al. 2013). The dominance of COD to $\mathrm{BOD}_{5}$ has largely been due to the presence of XOCs that increases COD. XOCs are synthetic organic compounds that are present in household chemicals and pharmaceuticals such as bleaches, surfactants, softeners and builders and beauty products. XOCs can also be formed by partial modification of chemicals in chemical or biological treatment of greywater (Fatta-Kassinos et al. 2011). XOCs are recalcitrant to conventional treatment protocols and can easily accumulate in plants and animals and subsequently pose risks to the natural environment (Fatta-Kassinos et al. 2011). Eriksson et al. (2002) identified 900 potential XOCs in greywater solely based on the ingredients of different cosmetics and detergents in Denmark. Le-Minh et al. (2010) identified the presence of antibiotics in greywater which may lead to proliferation of resistant bacteria strains. Revitt et al. (2011) also identified the presence of benzene and 4nitrophenol in greywater in appreciable concentrations. Other hazardous substances such as brominated flame retardants, polycyclic aromatic hydrocarbons, monocyclic aromatics, triclosans and phthalates have been identified in greywater (Palmquist and Hanaeus 2005). Table 2 presents some selected physicochemical parameters of greywater with their concentrations in some selected high- and low-income countries.

\section{Biological Characteristics}

Greywater contains microorganisms such as bacteria, protozoa and helminths which are introduced into it by body contact. Inappropriate food handling in the kitchen and direct handling of contaminated food have been identified as sources of enteric pathogenic bacteria such as Salmonella and Campylobacter into greywater (Maimon et al. 2014; Ottoson and Stenstrom 2003). Faecal contamination is also common in greywater and is largely associated with poor personal hygiene and disposal of greywater which contains washed nappies. Pathogenic Escherichia coli and enteric viruses have been detected in greywater with majority of the water originating from laundry sources during a microbial monitoring programme in Melbourne Australia (O'Toole et al. 2012). In this study, $18 \%$ of samples contained enteric viruses, $7 \%$ enterovirus and $11 \%$ of E. coli. The most common indicators used to assess faecal contamination are coliform bacteria and $E$. coli. Studies conducted by Eriksson et al. (2002) and Ottoson and Stenstrom (2003) revealed a large collection of excreta-related pathogens associated with greywater. Other studies have further identified a number of pathogens in greywater, and these are Pseudomonas (Benami et al. 2015a; Khalaphallah and Andres 2012), Legionella (Birks et al. 2004), Giardia (Birks et al. 2004; Birks and Hills 2007), Cryptosporidium (Birks et al. 2004) and Staphylococcus aureus (Benami et al. 2015a; Kim et al. 2009; Maimon et al. 2014; Shoults and Ashbolt 2017) in greywater. Table 3 presents some selected biological parameters with their concentrations as reported in other studies.

\section{Treatment Systems}

Management of greywater graduates from simple to extremely complex when the necessary strategies and technology is not in place or not properly implemented. Many developed countries have however implemented from simple to advanced methods of handling, managing and treating greywater with some countries recycling the greywater for both potable and nonpotable uses. Treatment systems have been used to reduce the level of contamination in greywater before reuse or final disposal. They are contaminant-specific, and each is applied along the conventional wastewater treatment sequence (pre-treatment, primary, secondary and tertiary treatment). Each of these systems adopts either a physicochemical or biological means of treatment. Physicochemical methods adopt physical and/or chemical methods of treatment including filtration, adsorption and reverse osmosis, among others. Biological 
Table 2 Physicochemical characteristic of greywater s in low- and high-income countries

\begin{tabular}{|c|c|c|c|c|c|c|c|c|}
\hline \multirow[t]{2}{*}{ Parameter } & \multicolumn{4}{|c|}{ Low-income countries } & \multicolumn{4}{|c|}{ High-income countries } \\
\hline & India $^{a}$ & Pakistan $^{\mathrm{b}}$ & Niger $^{\mathrm{c}}$ & Yemen $^{\mathrm{d}}$ & $\mathrm{USA}^{\mathrm{e}}$ & $U^{\mathrm{f}}$ & Spain $^{g}$ & Germany $^{\mathrm{h}}$ \\
\hline $\mathrm{pH}$ & $7.3-8.1$ & 6.2 & 6.9 & 6 & 6.4 & $6.6-7.6$ & 7.6 & 7.6 \\
\hline Turbidity (NTU) & - & - & 85 & 619 & 31.1 & $26.5-164$ & 20 & 29 \\
\hline $\mathrm{EC}(\mu \mathrm{S} / \mathrm{m})$ & - & - & - & - & 23 & 32.7 & - & 64.5 \\
\hline TSS (mg/L) & $100-283$ & 155 & - & 511 & 17 & $37-153$ & 32 & - \\
\hline TDS (mg/L) & 573 & 102 & - & - & 171 & - & - & - \\
\hline $\mathrm{BOD}_{5}(\mathrm{mg} / \mathrm{L})$ & $100-188$ & 56 & 106 & 518 & 86 & $39-155$ & - & 59 \\
\hline COD (mg/L) & $250-375$ & 146 & - & 2000 & - & $96-587$ & $151-177$ & 109 \\
\hline $\mathrm{Cl}(\mathrm{mg} / \mathrm{L})$ & 53 & - & - & - & - & - & - & - \\
\hline Oil and grease $(\mathrm{mg} / \mathrm{L})$ & 7 & - & - & - & - & - & - & - \\
\hline Nitrate (mg/L) & 0.67 & - & - & 98 & - & 3.9 & - & - \\
\hline T. Nitrate (mg/L) & - & - & - & - & 13.5 & $4.6-10.4$ & $10-11$ & 15.2 \\
\hline T. Phosp (mg/L) & 0.012 & - & - & - & 4 & $0.4-0.9$ & - & 1.6 \\
\hline $\mathrm{FC}(\mathrm{CFU})$ & - & - & - & 1.9 & - & - & - & $1.4 \times 10^{5}$ \\
\hline E. coli $(\mathrm{CFU})$ & - & - & - & - & $5.4 \times 10^{5}$ & $10-3.9 \times 10^{5}$ & - & - \\
\hline $\mathrm{Ca}(\mathrm{mg} / \mathrm{L})$ & 0.13 & - & - & - & - & - & - & - \\
\hline $\mathrm{Mg}(\mathrm{mg} / \mathrm{L})$ & 0.11 & - & - & - & - & - & - & - \\
\hline $\mathrm{Na}(\mathrm{mg} / \mathrm{L})$ & $32-50$ & - & - & - & - & - & - & - \\
\hline
\end{tabular}

${ }^{\text {a }}$ Parjane and Sane (2011)

${ }^{\mathrm{b}}$ Pathan et al. (2011)

${ }^{\mathrm{c}} \mathrm{Hu}$ et al. (2011)

${ }^{\mathrm{d}}$ Al-Mughalles et al. (2012)

e Jokerst et al. (2011)

${ }^{\mathrm{f}}$ Birks and Hills (2007); Pidou et al. (2008)

${ }^{\mathrm{g}}$ March and Gual (2007); March et al. (2004)

${ }^{\mathrm{h}}$ Merz et al. (2007)

Table 3 Biological characteristic of greywater in low- and high-income countries

\begin{tabular}{|c|c|c|}
\hline Name of microbe & Concentration & Source \\
\hline Total coliforms (counts/100 mL) & $1.2 \times 10^{3}-8.2 \times 10^{8}$ & $\begin{array}{l}\text { Alsulaili et al. (2017); Dwumfour-Asare et al. (2017); Mandal et al. (2011); } \\
\text { Masi et al. (2010); Oteng-Peprah et al. (2018) }\end{array}$ \\
\hline E. coli & Up to $6.5 \times 10^{6}$ & $\begin{array}{l}\text { Atanasova et al. (2017); Friedler et al. (2006a); Khalaphallah and } \\
\text { Andres (2012); Kim et al. (2009); Oteng-Peprah et al. (2018); } \\
\text { Paulo et al. (2009) }\end{array}$ \\
\hline Faecal coliforms & Up to $1 \times 10^{6}$ & Halalsheh et al. (2008); Mandal et al. (2011); Masi et al. (2010) \\
\hline Pseudomonas aeruginosa & $1.4 \times 10^{4}$ & Benami et al. (2015a); Khalaphallah and Andres (2012) \\
\hline Staphylococcus aureus & $1.2 \times 10^{2}-1.8 \times 10^{3}$ & $\begin{array}{l}\text { Benami et al. (2015b); Kim et al. (2009); Maimon et al. (2014); } \\
\text { Shoults and Ashbolt (2017) }\end{array}$ \\
\hline Salmonella typhi & $5.4 \times 10^{3}$ & Kim et al. (2009) \\
\hline Salmonella spp. & $3.1 \times 10^{3}$ & Oteng-Peprah et al. (2018) \\
\hline
\end{tabular}


treatment methods adopt a combination of microbes, sunlight and oxygen manipulation; examples of such systems include activated sludge systems, trickling filters, waste stabilization ponds, rotating biological contactors and many others. The widely used systems have mostly been filtration, rotating biological contactors, membrane bioreactors, constructed wetlands and upflow anaerobic sludge blankets (UASBs). These systems have found their application in addressing the emerging greywater pollution experienced in most developing countries. This review therefore discusses the performance of these systems.

\section{Filtration}

Filtration involves removal of particulate matter which is not removed by preceding processes. In filtration systems, both physical and biological processes remove solids; however, this review considers only physical removal of solids because that is the method adopted in most greywater treatment schemes. Filtration media could be in the form of sand, gravel, fine mesh and many others. Gross et al. (2007) studied the performance of a filtration system in greywater treatment using pebbles of $2 \mathrm{~cm}$ thick placed over drain holes and followed by a 12-cm middle layer consisting of $12 \mathrm{~cm}$ of plastic filter media and finally topped by $4 \mathrm{~cm}$ thick layer of peat. Dalahmeh et al. (2012) also studied the performance of a filtration system using pine bark, activated charcoal, polyurethane foam and sand as filter media in treating greywater. The performance of a coarse filtration system followed by slow sand filtration with a hydraulic retention time of 8 and $24 \mathrm{~h}$ respectively was studied by Finley et al. (2009). Parjane and Sane (2011) used coconut shell, coarse sawdust, charcoal, bricks and sand as filter materials to assess the performance of greywater treatment. A four-barrel filtration unit has been used to investigate greywater treatment by Al-Hamaiedeh and Bino (2010). These barrels were arranged in series, and the first three were loaded with gravels of $2-3 \mathrm{~cm}$ diameter. The final barrel was used to collect the treated effluent for irrigation. Gross (2008) adopted a hybrid filtration system utilizing a $130-\mu \mathrm{m}$ net filtration, a tuff filter, a sand filter and followed by electrolysis in Israel. Zuma et al. (2009) used a mulch tower system to treat greywater in South Africa. This was constructed by using mulch, coarse sand, fine and coarse gravel. This was contained in a $650-\mathrm{mm}$ high plastic column of $150 \mathrm{~mm}$ diameter with a stainless-steel sieve mesh placed on top to remove big particles. From the reviewed filtration systems, only bark filters were able to meet the $\mathrm{pH}$ criteria for reuse. More so, only the bark and charcoal filters could meet the $\mathrm{BOD}_{5}$ regulatory standard for reuse. Removal rates of total phosphorous were high in bark, charcoal and sand filters. The performance of filtration systems discussed is presented in Table 4 .

\section{Constructed Wetland}

Constructed wetland (CW) is an artificial wetland constructed utilizing ecological technology to mimic conditions that occur in a natural wetland. The technology adopts special flora and fauna, soil and microorganisms to remove pollutants of interest. They are normally classified under three main types namely subsurface flow, surface flow and floating treatment wetland. The subsurface flow systems have been the most widely used constructed wetlands, and they come in two main technologies, vertical flow constructed wetland (RVFCW) and horizontal flow constructed wetland (HFCW). Each removes contaminants by a combination of physical, chemical and biological processes, and the treatment efficiency depends on factors such as loading rate and the availability of electron acceptors (Halalsheh et al. 2008). They have high potential of removing $\mathrm{BOD}_{5}$, suspended solids and some heavy metals such as $\mathrm{Pb}$, $\mathrm{Zn}$ and Fe, among others. The performance of a RVFCW was studied, and it was observed that removal of ammonia nitrate was very low as compared to other systems (Gross et al. 2007; Travis et al. 2010). Gross (2008) also investigated the performance of HFCW in greywater treatment and observed that the quality of effluent improved if there was a pretreatment of the greywater. In this study, the average retention time was about $30 \mathrm{~h}$ and it was realized that electrical conductivity increased from 170 to $190 \mathrm{mS} / \mathrm{m}$, T-N was reduced from 31 to $23 \mathrm{mg} / \mathrm{L}$ and T-P was also reduced from 48 to $46 \mathrm{mg} / \mathrm{L}$ representing 25.8 and $4.2 \%$ respectively. One major advantage of $\mathrm{CW}$ is its ability to run on its own without the attention of an operator. However, its removal rates for $\mathrm{Na}, \mathrm{Ca}$ and $\mathrm{Mg}$ are relatively low and it also leads to increases in electrical conductivity (EC) which might be due to the dissolution of organic matter in the treated water leading to increase in the total dissolved solids (TDS) and subsequently affecting the EC. They are also unable to remove some microbiological agents such as 
Table 4 Treatment efficiencies of some selected greywater treatment systems

\begin{tabular}{|c|c|c|c|c|c|c|}
\hline Parameter & Filtration $^{\mathrm{a}}$ & Wetlands ${ }^{\mathrm{b}}$ & $\mathrm{SBR}^{\mathrm{c}}$ & $\mathrm{RBC}^{\mathrm{d}}$ & $\mathrm{MBR}^{\mathrm{e}}$ & $\mathrm{UASB}^{\mathrm{f}}$ \\
\hline Turbidity (NTU) & - & - & - & - & $98-99 \%$ & - \\
\hline $\mathrm{EC}(\mathrm{uS} / \mathrm{m})$ & - & - & - & - & - & - \\
\hline TSS (mg/L) & $53-93 \%$ & $90-98 \%$ & - & $9-12 \%$ & Up to $100 \%$ & - \\
\hline TDS (mg/L) & - & - & - & - & - & - \\
\hline $\mathrm{BOD}_{5}(\mathrm{mg} / \mathrm{L})$ & $89-98 \%$ & Up to $99 \%$ & $90-98 \%$ & $27-53 \%$ & $93-97 \%$ & Up to $67 \%$ \\
\hline COD (mg/L) & $37-94 \%$ & $81-82 \%$ & $90-98 \%$ & $21-61 \%$ & $86-99 \%$ & $38-79 \%$ \\
\hline $\mathrm{Cl}(\mathrm{mg} / \mathrm{L})$ & - & $92-94 \%$ & - & - & - & - \\
\hline Oil and grease $(\mathrm{mg} / \mathrm{L})$ & Up to $97 \%$ & Up to 95.45 & - & - & - & $83.7 \%$ \\
\hline Nitrate $(\mathrm{mg} / \mathrm{L})$ & $17-73 \%$ & - & - & - & $6-72 \%$ & - \\
\hline T. Nitrate (mg/L) & $5-98 \%$ & $26-82$ & $80 \%$ & - & $52-63 \%$ & 24 to $58 \%$ \\
\hline T. Phosp (mg/L) & Up to $100 \%$ & Up to $71 \%$ & - & - & Up to $19 \%$ & 10 to $39 \%$ \\
\hline $\mathrm{FC} \mathrm{(CFU)}$ & - & - & & $88.5-99.9 \%$ & Up to $99 \%$ & - \\
\hline E. coli $(\mathrm{CFU})$ & Up to $100 \%$ & - & & $88.5-99.9 \%$ & - & - \\
\hline $\mathrm{Ca}(\mathrm{mg} / \mathrm{L})$ & Up to $100 \%$ & - & - & - & - & - \\
\hline $\mathrm{Mg}(\mathrm{mg} / \mathrm{L})$ & Up to $100 \%$ & - & - & - & - & - \\
\hline $\mathrm{Na}(\mathrm{mg} / \mathrm{L})$ & $47 \%$ & - & - & - & - & - \\
\hline
\end{tabular}

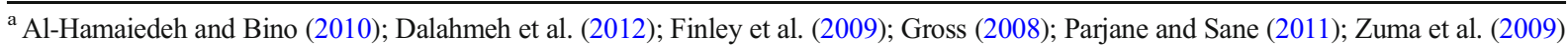

${ }^{\mathrm{b}}$ Gross (2008); Gross et al. (2007); Travis et al. (2010)

${ }^{\mathrm{c}}$ Hernandez Leal et al. (2010); Krishnan et al. (2008); Lamine et al. (2007); Scheumann and Kraume (2009)

${ }^{\mathrm{d}}$ Friedler et al. (2011); Gilboa and Friedler (2008); Pathan et al. (2011)

e Atanasova et al. (2017); Huelgas and Funamizu (2010); Jong et al. (2010); Merz et al. (2007)

${ }^{\mathrm{f}}$ Abdel-Shafy et al. (2015); Elmitwalli et al. (2007); Hernandez Leal et al. (2010)

E. coli and helminth eggs and as such will require further treatment if the objective of the treatment is reused. However, $\mathrm{CW}$ can produce effluents with $\mathrm{BOD}_{5}$ and TSS meeting the regulatory limits. The removal efficiencies of this discussed CW are presented in Table 4.

\section{Rotating Biological Contactors}

Rotating biological contactors (RBCs) are fixed bed reactors consisting of rotating disks and mounted on a horizontal shaft. They are partially submerged and rotated as wastewater flows through. The microbes that do the treatment are alternatively exposed to the atmosphere allowing both aeration and assimilation of dissolved organic pollutants and nutrients for degradation. Pathan et al. (2011) studied the performance of a single-stage RBC on greywater in Pakistan. The $\mathrm{RBC}$ was made of plastic sheets and the disks from textured plastic. The greywater was kept in the system for a specified period of time while the rotating discs were submerged up to $40 \%$ in the greywater. Friedler et al.
(2011) studied the potential of RBC to remove indicator bacteria (faecal coliforms, heterotrophic bacteria) and specific pathogens (Pseudomonas aeruginosa sp., Staphylococcus aureus sp.). The study concluded that RBC removed $88.5-99.9 \%$ of all four bacteria groups. Gilboa and Friedler (2008) studied the performance of RBC on removal of faecal coliforms (FC), Staphylococcus Aureus sp., Pseudomonas aeruginosa sp. and Clostridium perfringens sp. in greywater using $\mathrm{RBC}$ followed by sedimentation. The study concluded that the system removed up to $99 \%$ of all these microorganisms which were in the greywater. RBC systems perform well with respect to $\mathrm{pH}, \mathrm{BOD}_{5}, \mathrm{COD}$, reduced microbial loads and produced effluents that meet discharge guidelines. Performance of the system is presented in Table 4 .

\section{Sequencing Batch Reactor}

A sequencing batch reactor (SBR) is a type of activated sludge process used for wastewater treatment. All the treatment process takes place in batches in the reactor 
tank. The batch is sequenced through a series of treatment stages and performs equalization, biological treatment and secondary clarification in a single tank using a time-controlled sequence. Lamine et al. (2007) conducted a study on greywater treatment using SBR in a student house. This study assessed the performance of treatment by varying the hydraulic retention times (HRTs), and it revealed an effect on nitrification with the varying HRTs. A similar study by Scheumann and Kraume (2009) also used a pilot scale SBR by varying the retention time and observed the removal of COD, $\mathrm{NH}_{4}-\mathrm{N}$ and $\mathrm{TN}$ was sufficient to meet discharge reuse guidelines; however, there was nitrification in this study as also reported by Lamine et al. (2007). In this study, feedstock concentration of COD $250 \mathrm{mg} / \mathrm{L}, \mathrm{NH} 4-\mathrm{N} 11.9 \mathrm{mg} / \mathrm{L}$ and $\mathrm{TN}=$ 17.1 were reduced to $18.9,4.1$ and $0.37 \mathrm{mg} / \mathrm{L}$ respectively, all being below the mandatory values for reuse applications. Krishnan et al. (2008) investigated the performance of greywater treatment from residential houses in Malaysia on a square bottom SBR at fixed HRT. An SBR has also been used in a demonstration project in the Netherlands to treat greywater from 32 houses (Hernandez Leal et al. 2010). SBRs have removal efficiencies of up to $98 \%$ for $\mathrm{BOD}_{5}$ and COD, up to $80 \%$ $\mathrm{TN}$ and up to $99 \%$ for $\mathrm{NH}_{4}-\mathrm{N}$. The HRT has been found to be a limiting factor in the performance of SBRs since difference HRTs result in different effluent qualities as is shown in the different studies (Lamine et al. 2007; Scheumann and Kraume 2009). The performance of this system is presented in Table 4.

\section{Membrane Bioreactor}

A membrane bioreactor (MBR) is a perm-selective process integrated with a biological process for treating greywater. It works on a combination of biological, microfiltration and ultrafiltration systems to achieve treatment. It is an appropriate solution that can be used for greywater treatment and reused in densely urbanized areas, where space has high value, due to its compact size. Atanasova et al. (2017) studied the performance of an MBR on greywater treatment in a hotel in Spain. The removal efficiency for COD ranged from 80 to $95 \%$, where COD concentration in the effluent was below the quantification limit $30 \mathrm{mg} / \mathrm{L}$ based on the Spanish legislation for water reuse. Ammonia and TN removal were on average at high level 80.5 and $85.1 \%$ respectively. The treatment performance of an MBR made up of an ultrafitration membrane was also studied by Merz et al. (2007) on greywater from a sports complex in Morocco. Huelgas and Funamizu (2010) studied the treatment of greywater using a laboratory scale MBR under varying pressure. Jong et al. (2010) also used anaerobic-anoxicoxic MBR to treat greywater in Korea with microfilter of pore size $0.45 \mu \mathrm{m}$. These systems could achieve very good effluent which meets regulatory standards for reuse. A nominal pore size of $0.1 \mu \mathrm{m}$ has been found to remove faecal coliforms. Performance of this system is presented in Table 4.

\section{Upflow Anaerobic Sludge Blanket}

The upflow anaerobic sludge blanket (UASB) has remained one of the most widely used wastewater treatment system for various types of wastewater streams. It works on an anaerobic process and retains a high concentration of active suspended biomass and produces better settleable sludge than other treatment systems. Greywater from 32 houses in the Netherlands was treated using this system (Hernandez Leal et al. 2010). Elmitwalli et al. (2007) also used this system to study the treatment of greywater in Lubeck Germany by varying the retention time. Abdel-Shafy et al. (2015) investigated the efficiency of UASB in greywater treatment for unrestricted use in Egypt. The raw greywater characteristics with average concentrations of $95,392,298,10.45,0.4,118.5$ and $28 \mathrm{mg} / \mathrm{L}$ for TSS, COD, BOD 5 , TP, nitrates, oil and grease and TKN respectively were treated in a UASB. After treatment, the effluent concentration was $76.65,165.4$ 96.85 and $19.31 \mathrm{mg} / \mathrm{L}$ for TSS, COD, BOD 5 and oil and grease respectively. This represents removal efficiencies of $19.3 \%$ for TSS, $57.8 \%$ for COD, $67.5 \%$ for $\mathrm{BOD}_{5}$ and $83 \%$ for oil and grease. UASBs perform better when they are integrated with other systems. The performance of the system is presented in Table 4.

\section{Naturally Occurring Greywater Treatment Media}

These are naturally occurring materials that have been applied as either standalone media or used as a complementary medium in some of the available conventional greywater treatment systems. Many researchers have studied the effect of treatment offered by these media, and their performance is listed in Table 5. Unlike other 
conventional treatment systems, these media are used for removing targeted contaminants and their mode of treatment is either by adsorption, filtration or coagulation.

\section{Reuse Strategies}

A number of greywater treatment and reuse schemes have been implemented across the globe using both conventional and hybrid systems. Most of these systems have been developed as an environmental intervention measure and have since been operational while some have had their own challenges from both the technical and public point of view. Table 6 presents some examples of successful application of greywater treatment and reuse schemes in some countries.

\section{Greywater Reuse Perceptions}

Public perception which is a social phenomenon can be seen as the difference between an absolute truth based on facts and virtual truth shaped by popular opinion (Conjucture 2017). In implementation of any project, public perception has been recognized as an integral factor in determining the success of the project. Many technically sound and environmentally friendly programs have failed because it was not accepted by the intended beneficiaries. Several studies have been conducted to assess public perception towards greywater reuse in different parts of the world using different strategies. These strategies include interviews, questionnaires, focus group discussions, informal discussions and other equally good social surveys. Most of these surveys identified clear support for the concept of greywater reuse as an environmentally sustainable method of protecting freshwater resources and pollution prevention. It has been reported by Dolnicar and Schafer (2006), Friedler et al. (2006b), Hurliman and McKay (2007), Kantanonleon et al. (2007) and Marks (2004) that the highest acceptability of greywater reuse schemes are for non-potable uses. Dolnicar and Schafer (2006) identified reduced levels of acceptance as the recycled water got closer to human contact. A
Table 5 Naturally occurring materials for greywater treatment

\begin{tabular}{|c|c|c|c|c|}
\hline Type of material & $\begin{array}{l}\text { Target pollutant } \\
\text { removal }\end{array}$ & $\begin{array}{l}\text { Percentage } \\
\text { removal }(\%)\end{array}$ & $\begin{array}{l}\text { Mode of } \\
\text { removal }\end{array}$ & Source \\
\hline \multirow[t]{4}{*}{ Activated carbon } & $\mathrm{BOD}_{5}$ & 97 & \multirow[t]{4}{*}{ Adsorption } & \multirow[t]{4}{*}{ Sahar et al. (2012) } \\
\hline & COD & 94 & & \\
\hline & $\mathrm{TN}$ & 98 & & \\
\hline & $\mathrm{TP}$ & 91 & & \\
\hline \multirow[t]{2}{*}{ Activated charcoal } & $\mathrm{EC}$ & 12 & \multirow[t]{2}{*}{ Adsorption } & \multirow[t]{5}{*}{ Dalahmeh et al. (2012) } \\
\hline & $\mathrm{BOD}_{5}$ & 97 & & \\
\hline \multirow{3}{*}{$\begin{array}{l}\text { Peat moss and lime } \\
\text { pebbles }\end{array}$} & COD & 90 & \multirow[t]{3}{*}{ Filtration } & \\
\hline & $\mathrm{BOD}_{5}$ & 95 & & \\
\hline & E. coli & 100 & & \\
\hline \multirow[t]{4}{*}{ Pine bark } & $\mathrm{BOD}_{5}$ & 98 & \multirow[t]{4}{*}{ Adsorption } & \multirow[t]{4}{*}{ Sahar et al. (2012) } \\
\hline & COD & 74 & & \\
\hline & $\mathrm{TN}$ & 19 & & \\
\hline & $\mathrm{TP}$ & 97 & & \\
\hline \multirow[t]{6}{*}{ Moringa oleifera } & COD & 64 & \multirow[t]{6}{*}{ Coagulation } & Bhuptawat et al. (2007) \\
\hline & Turbidity & 98 & & \multirow[t]{5}{*}{ Hendrawati et al. (2016) } \\
\hline & Conductivity & 11 & & \\
\hline & $\mathrm{BOD}_{5}$ & 12 & & \\
\hline & Turbidity & 96 & & \\
\hline & TSS & 88 & & \\
\hline \multirow[t]{4}{*}{ Sawdust } & TSS & 83 & \multirow[t]{4}{*}{ Filtration } & \multirow[t]{4}{*}{ Parjane and Sane (2011) } \\
\hline & TDS & 70 & & \\
\hline & $\mathrm{O} \& \mathrm{G}$ & 97 & & \\
\hline & COD & 82 & & \\
\hline
\end{tabular}


Table 6 Greywater reuse strategies in some developing countries

\begin{tabular}{|c|c|c|c|c|}
\hline Location & System used & Application & Performance & Source \\
\hline Auroville, India & $\begin{array}{l}\text { Reed beds and irrigation } \\
\text { beds using banana }\end{array}$ & Treats greywater from a student dormitory & & Chuck (2004) \\
\hline Koulikoro, Mali & $\begin{array}{l}\text { Vertical flow filter and } \\
\text { greywater garden }\end{array}$ & $\begin{array}{l}\text { Treats greywater generated by a community } \\
\text { and the treated greywater is used in } \\
\text { subsurface irrigation of fruits and vegetables }\end{array}$ & & GTZ (2005) \\
\hline Mexico & Bioreactor and mulch bed & $\begin{array}{l}\text { Treats greywater for a rehabilitation } \\
\text { centre for children }\end{array}$ & & \\
\hline Djenne, Mali & Infiltration trench & $\begin{array}{l}\text { Was intended to stop the unregulated } \\
\text { discharge of greywater into the streets. } \\
\text { Unsightly conditions ceased within the } \\
\text { community because greywater was } \\
\text { discharged into trenches }\end{array}$ & & $\begin{array}{l}\text { Alderlieste and } \\
\text { Langeveld } \\
(2005)\end{array}$ \\
\hline $\begin{array}{l}\text { Gauteng, } \\
\text { South Africa }\end{array}$ & Tower garden & $\begin{array}{l}\text { Was intended to promote gardening due to } \\
\text { proximity to water for irrigation and } \\
\text { further empower the unemployed aged } \\
\text { financially. Leafy vegetables are planted } \\
\text { into the silts, and they are embraced by } \\
\text { many people. }\end{array}$ & & $\begin{array}{l}\text { Adendorff and } \\
\text { Stimie (2005) }\end{array}$ \\
\hline $\begin{array}{l}\text { Monteverde, } \\
\text { Costa Rica }\end{array}$ & $\begin{array}{l}\text { Constructed wetlands, } \\
\text { Submerged flow reedbeds }\end{array}$ & $\begin{array}{l}\text { Was intended to be used to treat greywater } \\
\text { from single households to prevent } \\
\text { discharge of greywater into the } \\
\text { environment. Treated greywater was used } \\
\text { to irrigate reeds which were an economic } \\
\text { plant. }\end{array}$ & & Dallas et al. (2004) \\
\hline $\begin{array}{l}\text { Kuching, } \\
\text { Malaysia }\end{array}$ & $\begin{array}{l}\text { Anaerobic filter, horizontal } \\
\text { flow planted filter }\end{array}$ & $\begin{array}{l}\text { An intervention to stop discharge of septic } \\
\text { tank effluent directly into stormwater } \\
\text { drains and subsequently into receiving } \\
\text { water }\end{array}$ & 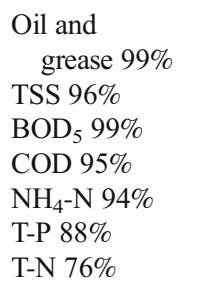 & Chong (2005) \\
\hline Billen, Palestine & $\begin{array}{l}\text { Anaerobic upflow filters, } \\
\text { aerobic filter }\end{array}$ & $\begin{array}{l}\text { Intended to reduce frequency of desludging } \\
\text { in a city which is water stressed }\end{array}$ & $\begin{array}{l}\text { TSS } 93-96 \% \\
\mathrm{BOD}_{5} 78-95 \% \\
\mathrm{PO}_{4}-\mathrm{N} 39-74 \% \\
\mathrm{NO}_{3}-\mathrm{N} \\
\quad 39-74 \%\end{array}$ & $\begin{array}{l}\text { Mahmoud } \\
\text { et al. (2003) }\end{array}$ \\
\hline Sri Lanka & $\begin{array}{l}\text { Anaerobic filter, } \\
\text { vertical-flow planted filter }\end{array}$ & $\begin{array}{l}\text { Greywater treatment systems in some } \\
\text { selected hotels and schools }\end{array}$ & & Harindra (2001) \\
\hline $\begin{array}{l}\text { Kathmandu, } \\
\text { Nepal }\end{array}$ & $\begin{array}{l}\text { Vertical flow planted } \\
\text { filter }\end{array}$ & $\begin{array}{l}\text { A local responsive approach to solve } \\
\text { problems of water scarcity in Nepal. The } \\
\text { greywater treated is reused for other } \\
\text { non-potable purposes while the impact of } \\
\text { this system leads to significant savings in } \\
\text { water expenditure. }\end{array}$ & $\begin{array}{l}\text { TSS } 97 \% \\
\mathrm{BOD}_{5} 98 \% \\
\text { COD } 93 \% \\
\mathrm{PO}_{4}-\mathrm{P} 33 \% \\
\mathrm{NH}_{4}-\mathrm{N} 96 \%\end{array}$ & $\begin{array}{l}\text { Shrestha } \\
\quad \text { et al. (2001) }\end{array}$ \\
\hline $\begin{array}{l}\text { Monteverde, } \\
\text { Costa Rica }\end{array}$ & $\begin{array}{l}\text { Horizontal-flow planted } \\
\text { filter }\end{array}$ & $\begin{array}{l}\text { An intervention to stop haphazard } \\
\text { discharge of greywater onto the streets } \\
\text { and into streams. This caused unsightly } \\
\text { conditions. After construction of this } \\
\text { system, conditions improved. }\end{array}$ & $\begin{array}{l}\mathrm{BOD}_{5} 99 \% \\
\mathrm{NH}_{4}-\mathrm{N} 95 \% \\
\mathrm{PO}_{4}-\mathrm{P} 84 \%\end{array}$ & $\begin{array}{l}\text { Dallas and } \\
\text { Ho (2005) }\end{array}$ \\
\hline Tufileh, Jordan & $\begin{array}{l}\text { Automated greywater } \\
\text { system }\end{array}$ & $\begin{array}{l}\text { Optimization and validation of a system for } \\
\text { reusing greywater in home gardens in Jordan }\end{array}$ & & Al-Jayousi (2003) \\
\hline
\end{tabular}

similar study by Jeffery (2001) in the UK identified that people were more willing to use 'own' recycled greywater than to use recycled water from an unknown source. Alhumoud and Madzikanda (2010) identified 
that public support was greater for areas which are water stressed and areas with unreliable water supply. The results of a study by Adewumi et al. (2010) conducted in three universities in South Africa among students and staff concluded that the level of education and level of awareness contribute to the success of greywater reuse. Religious and cultural practices have been identified as factors that influence reuse programs. This is supported by another study by DeSena (2006) and Parkinson (2008) who identified misinformation, lack of knowledge or instinctive repugnance as accounting for objections in reuse programs.

\section{Potable Reuse Perceptions}

The interruption and complete obstruction of many potable water reuse projects by stiff public opposition have been reported by DeSena (2006), Hurliman and Dolnicar (2013) and Meehan et al. (2013). This stiff opposition to potable reuse has been attributed to the close association of greywater with sewage which creates a phenomenon known as wisdom of repugnance. This phenomenon assumes that recycled water is associated with human waste; therefore, it renders it unpalatable from the public's point of view. A study by Marks (2004) in three developed countries (Australia, the USA and the UK) identified low public support and acceptance for greywater reuse for potable purposes. The main barrier encountered in these studies were the associated perceived health risk of reusing recycled water in activities that involve direct contact with the user. Other studies identified language of the names given to recycled water as one of the obstacles affecting reuse schemes (Dolnicar and Saunders 2006). A study by Friedler et al. (2006b), Omerod and Scott (2013) and Russell et al. (2009) identified public trust arising out of a combination of technical and non-technical issues. The study identified strong public opposition to reuse projects, where there is little trust in the implementing body even in the face of the most advanced technology applicable. Currently, most of the research in this area is targeting determinants that increases acceptance of reuse programs.

\section{Conclusions}

This study reviewed greywater characteristics, treatment systems, reuse strategies and perception of greywater reuse among users. It shows that there is a wide variation in greywater characteristics and volume generation rates which is largely dependent on the water use, lifestyle patterns and type of settlement. From the list of reviewed conventional treatment systems, filtration methods seem feasible and have the potential of integration with other systems to achieve target specific treatment. The study described different reuse strategies, most using discharged greywater for food production and landscaping while others have been used for poverty alleviation in irrigation farming.

The available technologies have been developed to treat or remove specific pollutants and not offer a full treatment of the greywater. Moreover, quality criteria differ for each type of reuse application, and greywater composition and generation rates vary greatly from one point to the other. It will therefore be prudent if systems are designed to target a specific reuse option taking into consideration the regional variability and complexities such that effluent from a treatment system will meet the required effluent guidelines. All the treatment systems reviewed were applicable on a large scale and cannot be applied at the household level. This in our view discourages local level participation in greywater reuse schemes. From the review, the potential of some natural materials to be used as media in greywater treatment systems also emerged. These natural materials are widely available in most developing countries, and their total integration into the conventional treatment systems should be explored. They can be used to design simple household level greywater treatment systems that target a certain reuse option and thereby increase local level participation.

Perception of greywater reuse has been closely related to the choice of reuse as most users will want to reuse greywater for activities that do not involve personal contact. In general, public perceptions are important to consider when implementing a certain method for a specified use. On the basis of this review, we conclude that to achieve effective greywater treatment and reuse, extensive contributions from technical and non-technical experts in many disciplines are called for. It also requires a comprehensive assessment of the greywater characteristics in order to choose an appropriate method or system of treatment. That notwithstanding, greywater treatment and reuse if embraced and enforced can lead to substantial decline in over-reliance on freshwater resources for non-potable uses. 
Open Access This article is distributed under the terms of the Creative Commons Attribution 4.0 International License (http:// creativecommons.org/licenses/by/4.0/), which permits unrestricted use, distribution, and reproduction in any medium, provided you give appropriate credit to the original author(s) and the source, provide a link to the Creative Commons license, and indicate if changes were made.

\section{References}

Abdel-Shafy, H. I., Al-Sulaiman, A. M., \& Mansour, M. S. (2015). Anaerobic/aerobic treatment of greywater via UASB and MBR for unrestricted reuse. Water Science and Technology, 71, 630-637. https://doi.org/10.2166/wst.2014.504.

Abedin, S. B., \& Rakib, Z. B. (2013). Generation and quality analysis of greywater at Dhaka City. Environmental Research, Engineering and Management, 64, 29-41. https://doi.org/10.5755/j01.erem.64.2.3992.

Adendorff J, Stimie C (2005) Food from used water-making the previously impossible happen. South African Research Commission (WRC). http://journals.co. $\mathrm{za} /$ docserver/fulltext/waterb/4/1/waterb_v4_n1_a4. pdf?expires $=1493811214 \&$ id=id\&accname $=$ guest\&checksum=510AA057CDF6FD48ADB3BCB40047 FFDC. Accessed 2nd April 2017.

Adewumi, J. R, Olanrewaju, O. O, Ilemobade, A. A, van Zyl, J. E (2010) Perceptions towards greywater reuse and proposed model for institutional and commercial settlements in South Africa. In: WISA Biennial Conference and Exhibitions, South Africa, 2010. vol 25th April. 2017,

Al-Hamaiedeh, H., \& Bino, M. (2010). Effect of treated grey water reuse in irrigation on soil and plants. Desalination, 256, 115119. https://doi.org/10.1016/j.desal.2010.02.004.

Al-Jayousi, O. R. (2003). Greywater reuse: towards sustainable water management. Desalination, 165, 181-192.

Al-Mughalles, M. H., Rahman, R. A., Suja, F. B., Mahmud, M., \& Jahil, N. A. (2012). Household greywater quantity and quality in Sana'a, Yemen. EJGE, 17, 1025-1034.

Alderlieste, M. C., \& Langeveld, J. G. (2005). Wastewater planning in Djenne, Mali. A pilot project for the local infiltration of domestic wastewater. Water Science and Technology, 51, 57-64.

Alhumoud J. M, Madzikanda D (2010) Public perceptions on water reuse options: the case of Sulaibiya wastewater treatment plant in Kuwait International Business and Economics Research Journal Vol 9(1).

Alsulaili, A. D., \& Hamoda, M. F. (2015). Quantification and characterization of greywater from schools. Water Science and Technology, 72, 1973-1980. https://doi.org/10.2166 /wst.2015.408.

Alsulaili, A. D., Hamoda, M. F., Al-Jarallah, R., \& Alrukaibi, D. (2017). Treatment and potential reuse of greywater from schools: a pilot study. Water Science and Technology, 75, 2119-2129. https://doi.org/10.2166/wst.2017.088.

Aonghusa, C. N., \& Gray, N. F. (2002). Laundry detergents as a source of heavy metals in Irish domestic wastewater. Journal of Environmental Science and Health. Part A, Toxic/
Hazardous Substances \& Environmental Engineering, 37, $1-6$.

Atanasova, N., Dalmau, M., Comas, J., Poch, M., RodriguezRoda, I., \& Buttiglieri, G. (2017). Optimized MBR for greywater reuse systems in hotel facilities. Journal of Environmental Management, 193, 503-511. https://doi. org/10.1016/j.jenvman.2017.02.041.

Benami, M., Gillor, O., \& Gross, A. (2015a). The question of pathogen quantification in disinfected graywater. Science of the Total Environment, 506, 496-504. https://doi. org/10.1016/j.scitotenv.2014.11.051.

Benami, M., Gillor, O., \& Gross, A. (2015b). The question of pathogen quantification in disinfected graywater. Sci Total Environ, 506-507, 496-504. https://doi.org/10.1016/j. scitotenv.2014.11.051.

Bhuptawat, H., Folkard, G. K, Chaudhari, S. (2007) Innovative physico-chemical treatment of wastewater incorporating Moringa oleifera seed coagulant. http://dspace.library.iitb. ac.in/jspui/bitstream/10054/1654/1/5253-1.pdf. Accessed 18 th April 2017.

Birks, R., Colbourne, J., Hills, S., \& Hobson, R. (2004). Microbiological water quality in a large in-building, water recycling facility. Water Science and Technology, 50, 165-172.

Birks, R., \& Hills, S. (2007). Characterisation of indicator organisms and pathogens in domestic greywater for recycling. Environmental Monitoring and Assessment, 129, 61-69. https://doi.org/10.1007/s10661-006-9427-y.

Boyjoo, Y., Pareek, V. K., \& Ang, M. (2013). A review of greywater characteristics and treatment processes. Water Science and Technology, 67, 1403-1424. https://doi. org/10.2166/wst.2013.675.

Busser, S, Pham, T. N, Morel, A, Nguyen, V. A (2006) Characterisitcs and quantities of domestic wastewater in urban and peri-urban households in Hanoi. http://ir.library.osaka-u.ac. jp/dspace/bitstream/11094/13204/1/arfyjsps2006_395.pdf. Accessed 19th March 2017.

Casanova, L. M., Gerba, C. P., \& Karpiscak, M. (2001). Chemical and microbial characterization of household greywater. Journal of environmental science and health, Part A. Toxic/ Hazardous Substances and Environmental Engineering, 34, 395-401.

Chong, B (2005) Implementation of an urban pilot scale ecological sanitation wastewater treatment system in Kuching Sarawak, Malaysia vol No. UEMS_TEC_20_45. Natural Resources and Environment Board Sarawak, Malaysia.

Chuck, H. (2004) Composting toilet and greywater system. http://www.aviusa.org/projects_usapavilion_newsletter_ may_aug_2006.pdf. Accessed 12 April 2017.

Ciabatti, I., Cesaro, F., Faralli, L., Fatarella, E., \& Tognotti, F. (2009). Demonstration of a treatment system for purification and reuse of laundry wastewater. Desalination, 245, 451459. https://doi.org/10.1016/j.desal.2009.02.008.

Conjucture, C. (2017) What is public perception. http://www. wisegeek.com/what-is-public-perception.htm. Accessed 25 November 2017.

Dalahmeh, S. S., Pell, M., Vinneras, B., Hylander, L. D., Oborn, I., \& Jonsson, H. (2012). Efficiency of bark, activated charcoal, foam and sand filters in reducing pollutants from greywater. Water, Air, and Soil Pollution, 223, 3657-3671. https://doi. org/10.1007/s11270-012-1139-z. 
Dallas, S., \& Ho, G. (2005). Subsurface flow reedbeds using alternative media for the treatment of domestic greywater in Monteverde Costa Rica, Central America. Water Science and Technology, 52, 119-128.

Dallas, S., Sceffe, B., \& Ho, G. (2004). Reedbeds for greywater treatment - case study in Santa Elena-Monteverde, Costa Rica, Central America. Ecological Engineering, Elsevier, 23, 55-61. https://doi.org/10.1016/j.ecoleng.2004.07.002.

De Sena, N. (2006). Public opposition sidelines indirect potable reuse projects. Water and Environment Technology, 1999, $11-16$.

de Aguir do Couto, E., Calijuri, M. L., Assemany, P. P., da Fonseca Santiago, A., \& de Castro Carvalho, I. (2013). Greywater production in airports: qualitative and quantitative assessment resources. Conservation and Recycling, 77, 44-51. https://doi.org/10.1016/j.resconrec.2013.05.004.

Dolnicar, S., \& Saunders, C. (2006). Recycled water for consumer markets - a marketing research review and agenda. Desalination, 187.

Dolnicar, S., Schafer AI 2006 Public perception of desalinated versus recycled water in Australia. In: AWWA Desalination Symposium, Honolulu, Hawai.

Dwumfour-Asare, B., Adantey, P., Nyarko, K. B., \& AppiahEffah, E. (2017). Greywater characterization and handling practices among urban households in Ghana: the case of three communities in Kumasi Metropolis. Water Science and Technology, 76, 813-822. https://doi.org/10.2166 /wst.2017.229.

Eakin BW, Sharman GF (2010) Volumes of the world's oceans from ETOPO1. NOAA, National Geophysical Data Center. https://www.ngdc.noaa.gov/mgg/global/etopo1_ocean volumes.html. Accessed 22nd October 2017.

Edwin, G. A., Gopalsamy, P., \& Muthu, N. (2014). Characterization of domestic gray water from point source to determine the potential for urban residential reuse: a short review. Applied Water Science, 4, 39-49. https://doi. org/10.1007/s 13201-013-0128-8.

Effendi H, Sari DR, Hasibuan S (2015) Moringa oleifera as coagulant for batik effluent treatment. In: 35th Annual Conference of the International Association for Impact Assessment, Firenze Fiera Congress and Exhibition Center, Florence.

Elmitwalli, T. A., Shalabi, M., Wendland, C., \& Otterpohl, R. (2007). Grey water treatment in UASB reactor at ambient temperature. Water Science and Technology, 55, 173-180.

Eriksson, E., Auffarth, K., Eilersen, A. M., Henze, M., \& Ledin, A. (2003). Household chemicals and personal care products as sources for xenobiotic organic compounds in grey wastewater. Water SA, 29, 135-146.

Eriksson, E., Auffarth, K., Henze, M., \& Ledin, G. (2002). Characteristics of grey wastewater. Urban Water, 4, 85-104.

Eriksson, E., Srigirisetty, S., \& Eilersen, A. M. (2010). Organic matter and heavy metals in grey-water sludge. Water $S A, 36$, 139-142.

Faraqui, N., \& Al-Jayyousi, O. (2002). Greywater reuse in urban agriculture for poverty alleviation. A case study in Jordan. Water International, 27, 387-394.

Fatta-Kassinos, D., Kalavrouziotis, I. K., Koukoulakis, P. H., \& Vasquez, M. I. (2011). The risks associated with wastewater reuse and xenobiotics in the agroecological environment. $\mathrm{Sci}$
Total Environ, 409, 3555-3563. https://doi.org/10.1016/j. scitotenv.2010.03.036.

Finley, S., Barrington, S., \& Lyew, D. (2009). Reuse of domestic greywater for the irrigation of food crops. Water Air Soil Poll, 199, 235-245. https://doi.org/10.1007/s11270-008-9874-x.

Friedler, E., Kovalio, R., \& Ben-Zvi, A. (2006a). Comparative study of the microbial quality of greywater treated by three on-site treatment systems. Environmental Technology, 27, 653-663. https://doi.org/10.1080/09593332708618674.

Friedler, E., Lahav, E., Jizhaki, H., \& Lahav, T. (2006b). Study of urban population attitudes towards various wastewater reuse options: Israel as a case study. Journal of Environmental Management, 81, 360-370.

Friedler, E., Yardeni, A., Gilboa, Y., \& Alfiya, Y. (2011). Disinfection of greywater effluent and regrowth potential of selected bacteria. Water Science and Technology, 63, 931940. https://doi.org/10.2166/wst.2011.272.

Gilboa, Y., \& Friedler, E. (2008). UV disinfection of RBC-treated light greywater effluent: kinetics, survival and regrowth of selected microorganisms. Water Research, 42, 1043-1050. https://doi.org/10.1016/j.watres.2007.09.027.

Gleick, P. (1993). Water in crisis: a guide to the world's fresh water resources. Oxford: Oxford University Press.

Gross, A. (2008). Reliability of small scale greywater treatment systems and the impact of its effluent on soil properties. International Journal of Environmental Studies, 65, 41-50.

Gross, A., Shmueli, O., Ronen, Z., \& Raveh, E. (2007). Recycled vertical flow constructed wetland (RVFCW) - a novel method of recycling greywater for irrigation in small communities and households. Chemosphere, 66, 916-923. https://doi. org/10.1016/j.chemosphere.2006.06.006.

GTZ (2005) Ecosan project. Urban upgrading project. http://www. indiawaterportal.org/sites/indiawaterportal.org/files/ecosan $\mathrm{cd} / \mathrm{material} / \mathrm{D}$ recommended-reading/07 project-datasheets/en-ecosan-pds-010-mali-koulikoro-2005.pdf. Accessed 12 April 2017.

Halalsheh, M., Dalahmeh, S., Sayed, M., Suleiman, W., Shareef, M., Mansour, M., \& Safi, M. (2008). Grey water characteristics and treatment options for rural areas in Jordan. Bioresource Technology, 99, 6635-6641. https://doi. org/10.1016/j.biortech.2007.12.029.

Harindra, C. (2001). Appropriate disposal of sewage in urban and suburban Sri Lanka. UK: University of Leeds.

Hendrawati, Yuliastri, R. I, Nurhasni, Rohaeti, E., Effendi, H., Darusman, K. L. (2016) The use of Moringa oleifera seed powder as coagulant to improve the quality of wastewater and ground water Earth and Environmental Science 31.

Hernandez Leal, L., Temmink, H., Zeeman, G., \& Buisman, C. (2010). Comparison of three systems for biological greywater treatment. Water, 2, 155-169.

$\mathrm{Hu} \mathrm{M}$ et al. Treatment of greywater with shredded-tire biofilters and membrane bioreactors. In: World Environmental and Water Resources Congress: bearing knowledge for sustainability, 2011. ASCE, pp 1877-1887.

Huelgas, A., \& Funamizu, N. (2010). Flat-plate submerged membrane bioreactor for the treatment of higher-load graywater. Desalination, 250, 162-166. https://doi.org/10.1016/j. desal.2009.05.007.

Hurliman, A., \& Dolnicar, S. (2013). When public opposition defeats alternative water projects - the case of Toowoomba Australia. Water Resources, 44, 287-297. 
Hurliman, A., \& McKay, J. (2007). Urban Australia using recycled water for domestic non-potable use - an evaluation of the attributes price, saltiness, colour and odour using conjoint analysis. Journal of Environmental Management, 83, 93104.

Jakobi G, Lohr A (1987) Detergents and textile washing. VCH, Weinheim.

Jamrah, A., Al-Futaisi, A., Prathapar, S., \& Harrasi, A. A. (2008). Evaluating greywater reuse potential for sustainable water resources management in Oman. Environmental Monitoring and Assessment, 137, 315-327. https://doi.org/10.1007 /s10661-007-9767-2.

Jamrah, A., Al Omari, A., Al Qasem, L., \& Abdel Ghani, N. (2011). Assessment of availability and characteristics of greywater in Amman. Water Science and Technology, 50, $157-164$.

Jeffery, P. (2001). Understanding public receptivity issues regarding 'in-house' water recycling. Cranfield UK: Results from a UK survey.

Jokerst, A., Sharvelle, S. E., Hollowed, M. E., \& Roesner, L. A. (2011). Seasonal performance of an outdoor constructed wetland for graywater treatment in a temperate climate. Water Environment Research, 83, 2187-2198.

Jong, J., Lee, J., Kim, J., Hyun, K., Hwang, T., Park, J., \& Choung, Y. (2010). The study of pathogenic microbial communities in graywater using membrane bioreactor. Desalination, 250, 568-572. https://doi.org/10.1016/j.desal.2009.09.025.

Kantanonleon, N., Zampetakis, L., \& Manios, T. (2007). Public perception towards wastewater reuse in a medium size, seaside Mediterranean city: a pilot survey. Resources Conservation and Recycling, 50, 282-292.

Katukiza, A. Y., Ronteltap, M., Niwagaba, C. B., Kansiime, F., \& Lens, P. N. L. (2014). Grey water characterisation and pollutant loads in an urban slum. International Journal of Environmental Science and Technology, 12, 423-436. https://doi.org/10.1007/s13762-013-0451-5.

Khalaphallah, R., \& Andres, Y. (2012). The effect of various abiotic factors on the survival growth of Escherichia coli and Pseudomonas aeruginosa in bathroom greywater. $J$ Water Reuse Desal, 2, 92-101. https://doi.org/10.2166 /wrd.2012.076.

Kim, J., Song, I., Oh, H., Jong, J., Park, J., \& Choung, Y. (2009). A laboratory-scale graywater treatment system based on a membrane filtration and oxidation process - characteristics of graywater from a residential complex. Desalination, 238, 347-357. https://doi.org/10.1016/j.desal.2008.08.001.

Krishnan, V., Ahmad, D., \& Jeru, J. B. (2008). Influence of COD:N:P ratio on dark greywater treatment using a sequencing batch reactor. Journal of Chemical Technology and Biotechnology, 83, 756-762. https://doi.org/10.1002/jctb.1842.

Lamine, M., Bousselmi, L., \& Ghrabi, A. (2007). Biological treatment of grey water using sequencing batch reactor. Desalination, 215, 127-132. https://doi.org/10.1016/j. desal.2006.11.017.

Lange, K. R. (1994) Detergents and cleaners: a handbook for formulators. Schoder Druck GmbH and Co. KG, New York.

Le-Minh, N., Khan, S. J., Drewes, J. E., \& Stuetz, R. M. (2010). Fate of antibiotics during municipal water recycling treatment processes. Water Research, 44, 4295-4323. https://doi. org/10.1016/j.watres.2010.06.020.
Ledin A, Eriksson E, Henze M (2001) Aspects of groundwater recharge using grey wastewater. In: Lens P, Zeeman G, Lettinga $G$ (eds) Decentralised sanitation and reuse: concepts, systems and implementation IWA Publishing, London, pp 354-370.

Li, F., Wichmann, K., \& Otterpohl, R. (2009). Review of the technological approaches for grey water treatment and reuses. Science of the Total Environment, 407, 3439-3449. https://doi.org/10.1016/j.scitotenv.2009.02.004.

Mahmoud, N., Amarneh, M. N., Al-Sa'ed, R., Gijzen, H., \& Lettinga, G. (2003). Sewage characterization as a tool for the application of anaerobic treatment in Palestine. Environmental Pollution, 126, 115-122.

Maimon, A., Friedler, E., \& Gross, A. (2014). Parameters affecting greywater quality and its safety for reuse. Science of the Total Environment, 487, 20-25. https://doi.org/10.1016/j. scitotenv.2014.03.133.

Mandal, D., Labhasetwar, P., Dhone, S., Dubey, A. S., Shinde, G., \& Wate, S. (2011). Water conservation due to greywater treatment and reuse in urban setting with specific context to developing countries. Resources Conservation and Recycling, 55, 356-361. https://doi.org/10.1016/j. resconrec.2010.11.001.

March, J. G., \& Gual, M. (2007). Breakpoint chlorination curves of greywater. Water Environment Research, 79, 828-832.

March, J. G., Gual, M., \& Simonet, B. M. (2004). A sensitive extracto-photometric method for determination of residual chlorine in greywater. Journal of AOAC International, 87, $852-855$.

Marks, M. (2004). Advancing community acceptance of reclaimed water. Water Journal of the Australian Water Association, 31, 46-51.

Masi, F., El Hamouri, B., Abdel Shafi, H., Baban, A., Ghrabi, A., \& Regelsberger, M. (2010). Treatment of segregated black/ grey domestic wastewater using constructed wetlands in the Mediterranean basin: the zer0-m experience. Water Science and Technology, 61, 97-105. https://doi.org/10.2166 /wst.2010.780.

Meehan, K., Ormerod, K. J., Moore S. (2013) Remaking waste as water: the governance of recycled effluent for potable water supply Water Alternative 67-85.

Merz, C., Scheumann, R., El Hamouri, B., Kraume M (2007) Membrane bioreactor technology for the treatment of greywater from a sports and leisure club. 215:37-43.

Morel, A., Diener, S. (2006) Greywater management in low and middle-income countries, review of different treatment systems for households or neighbourhoods. Swiss Federal Institue of Aquatic Science and Technology (EAWAG),

O'Toole, J., Sinclair, M., Malawaraarachchi, M., Hamilton, A., Barker, S. F., \& Leder, K. (2012). Microbial quality assessment of household greywater. Water Research, 46, 43014313. https://doi.org/10.1016/j.watres.2012.05.001.

Omerod, K. J., \& Scott, C. A. (2013). Drinking wastewater: public trust in potable reuse. Science Technology and Human Values, 38, 351-373.

Oteng-Peprah, M., de Vries, N. K., \& Acheampong, M. A. (2018). Greywater characterization and generation rates in a peri urban municipality of a developing country. Journal of Environmental Management, 206, 498-506. https://doi. org/10.1016/j.jenvman.2017.10.068. 
Ottoson, J., \& Stenstrom, T. A. (2003). Faecal contamination of greywater and associated microbial risks. Water Research, 37, 645-655.

Palmquist, H., \& Hanaeus, J. (2005). Hazardous substances in separately collected grey- and blackwater from ordinary Swedish households. Science of the Total Environment, 348, 151-163. https://doi.org/10.1016/j.scitotenv.2004.12.052.

Parjane, S. B., \& Sane, M. G. (2011). Performance of greywater treatment plant by economical way for Indian rural development. Int J Chem Tech Res, 3, 1808-1815.

Parkinson, J. (2008). Waste not: the facts about indirect potable reuse. Humanist, 68, 4-6.

Pathan, A. A., Mahar, R. B., \& Ansari, K. (2011). Preliminary study of greywater treatment through rotating biological contactor Mehran Univ Res. Journal of Engineering Technology, 30, 531-538.

Paulo, P. L., Begosso, L., Pansonato, N., Shrestha, R. R., \& Boncz, M. A. (2009). Design and configuration criteria for wetland systems treating greywater. Water Science and Technology, 60, 2001-2007. https://doi.org/10.2166/wst.2009.542.

Pidou, M., et al. (2008). Chemical solutions for greywater recycling. Chemosphere, 71, 147-155. https://doi. org/10.1016/j.chemosphere.2007.10.046.

Prathapar, S. A., Jamrah, A., Ahmed, M., Al Adawi, S., Al Sidairi, S., \& Al Harassi, A. (2005). Overcoming constraints in treated greywater reuse in Oman. Desalination, 186, 177186. https://doi.org/10.1016/j.desal.2005.01.018.

Qureshi, M. E., \& Hanjra, M. A. (2010). Global water crisis and future security in an era of climate change. Food Policy, 35, 365-377. https://doi.org/10.1016/j.foodpol.2010.05.006.

Revitt, D. M., Eriksson, E., \& Donner, E. (2011). The implications of household greywater treatment and reuse for municipal wastewater flows and micropollutant loads. Water Research, 45, 1549-1560. https://doi.org/10.1016/j.watres.2010.11.027.

Russell, S., Lux, C., \& Hampton, G. (2009). Information: integrating consultation and education for water recycling initiatives. Social and Natural Resrouces, 22, 46-65.
Sahar, S. D., Mikael, P., Bjorn, V., Lars, D. H., Ingrid, O., \& Hakan, J. (2012). Efficiency of bark, activated charcoal, foam and sand filters in reducing pollutants from greywater. Water, Air, and Soil Pollution, 223, 3657-3671.

Scheumann, R., \& Kraume, M. (2009). Influence of hydraulic retention time on the operation of a submerged membrane sequencing batch reactor (SM-SBR) for the treatment of greywater. Desalination, 246, 444-451. https://doi. org/10.1016/j.desal.2008.03.066.

Shoults, D. C, Ashbolt, N. J (2017) UV disinfection of hand-rinse greywater and performance testing using indigenous Staphylococcus spp. Water 9 doi:https://doi.org/10.3390 /w9120963.

Shresta, R. R. (1999). Application of constructed wetlands for wastewater treatment in Nepal. Vienna: University of Agricultural Sciences.

Shrestha, R. R., Haberl, R., \& Laber, J. (2001). Application of constructed wetlands for wastewater treatment in Nepal. Water Science and Technology, 44, 381-386.

Travis, M. J., Wiel-Shafran, A., Weisbrod, N., Adar, E., \& Gross, A. (2010). Greywater reuse for irrigation: effect on soil properties. Science of the Total Environment, 408, 25012508. https://doi.org/10.1016/j.scitotenv.2010.03.005.

UNDP (2017) Sustainable development goals. Goal 6 targets facts and figures. http:/www.undp.org/content/undp/en/home/sustainabledevelopment-goals/goal-6-clean-water-and-sanitation/targets/. Accessed 23/11 2017.

Vigneswaran, S., \& Sundaravadivel, M. (2004). Recycle and reuse of domestic wastewater in wastewater recycle, reuse and reclamation. Oxford: EOLSS.

Zuma, B. M., Tandlich, R., Whittington-Jones, K. J., \& Burgess, J. E. (2009). Mulch tower treatment system. Part 1: overall performance in greywater treatment. Desalination, 242, 3856. 